\title{
GAYA KEPEMIMPINAN DAN MOTIVASI KERJA PEGAWAI PD. BPR BANK DAERAH LAMONGAN
}

\author{
*(Ruswaji \\ Fakultas Ekonomi \\ Universitas Islam Lamongan
}

\begin{abstract}
ABSTRAK
Tujuan penelitian adalah untuk mengidentifikasi dan menggambarkan style kepemimpinan dan motivasi karyawan untuk bekerja di PD. BPR Bank Daerah Lamongan. Metode penelitian yang digunakan adalah penelitian kualitatif dengan mengumpulkan data melalui wawancara, observasi dan dokumentasi. Informan diperoleh berdasarkan pertimbangan dari peneliti, mereka yang memberikan tujuan dan informasi yang akurat sesuai dengan masalah penelitian. Informan diambil dari karyawan PD. BPR Bank Daerah Lamongan dengan total 84 yang terdiri dari sepuluh informan di frontliner, lima puluh empat dari pemasaran dan dua puluh dari back office.

Hasil penelitian menunjukkan gaya kepemimpinan cenderung ke arah partisipatif karena menampung saran, usulan dan pendapat dari bawahan dengan menggunakan aturan yang ketat dan disiplin untuk mempengaruhi bawahan, karyawan diminta untuk melaksanakan ketentuan standar pelayanan (SOP) untuk frontliner atas permintaan atau permintaan dari manajemen. Sebagian frontliners yang diperlukan untuk memenuhi tuntutan standar pelayanan tanpa tawarmenawar untuk kemajuan PD. BPR Bank Daerah Lamongan. Pemimpin menerima saran dan usulan yang diajukan bawahan karena bawahan berada di garis terdepan dalam menerima komentar dari pelanggan. Motivasi karyawan saat ini bekerja seperti untuk mencapai karir terbaik, dapatkan gaji tinggi, fasilitas yang tidak memadai dan mendapatkan pensiun yang memadai.

Dapat disarankan bahwa dalam meningkatkan kinerja bank sesuai dengan tujuan, visi dan misi PD. BPR Bank Daerah Lamongan menjadi gaya kepemimpinan partisipatif yang disesuaikan untuk membiarkan dipelihara bahkan mendengarkan apa yang diinginkan pelanggan sebagai pelanggan. Pemimpin harus mencatat karyawan yang mengalami demotivasi disebabkan oleh terlalu jenuh dengan situasi dan kondisi kerja dengan menyediakan berbagai tugas, dan menciptakan suasana kondusif di tempat kerja.
\end{abstract}

Kata Kunci: Gaya Kepemimpinan dan Motivasi Kerja Pegawai.

\section{PENDAHULUAN}

Sebagai sebuah institusi perbankan dan merupakan salah satu aset daerah Kabupaten Lamongan, PD. BPR Bank Daerah Lamongan menyandang visi untuk menjadi bank yang terdepan dan terpercaya dalam menggerakan ekonomi di Lamongan. Misi PD. BPR Bank Daerah Lamongan ialah (1) Memberantas lintah darat, (2) Memberi pinjaman dalam bidang perdagangan dan pengusaha ekonomi lemah, (3) Memperluas kesempatan kerja bagi masyarakat luas, (4) Mendidik masyarakat untuk menabung, (5) Menambah pendapatan asli Daerah, (6) Sebagai agent of development. 
Di dalam upaya mewujudkan visi dan misi tersebut, PD. BPR Bank Daerah Lamongan sangat membutuhkan human capital yang memiliki integritas tinggi, yang handal, terpercaya disiplin, berdedikasi tinggi. Sebagai tulang punggung sebuah perusahaan, PD. BPR Bank Daerah Lamongan sangat peduli dalam peningkatan kualitas para pegawai. Penataan, perbaikan, dan penyempurnaan sumber daya manusia harus diarahkan guna peningkatan kualitas sehingga dapat memanfaatkan peluang-peluang yang ada, juga sanggup mengatasi setiap ancaman yang akan datang, dan bahkan mampu mengubah ancaman yang datang tersebut menjadi kekuatan. Kesemuanya akan berhubungan dengan meningkatnya produktivitas para pegawai guna mendukung pencapaian kinerja yang optimal.

Di dalam lingkungan kerja, para pemimpin berperan dalam mempengaruhi moral dan memberi motivasi kepada bawahan (Susanto, 2008). Seorang pemimpin harus memiliki ketrampilan untuk dapat bersikap dan berperilaku efektif dalam menjalankan tugasnya. Gaya kepemimpinan akan mengarahkan, mengatur, dan mengkoordinir para bawahan untuk dapat melaksanakan tugas pekerjaan yang telah ditetapkan. Sebagaimana pendapat Thoha (2004) bahwa gaya kepemimpinan merupakan norma perilaku yang digunakan oleh seorang pada saat orang tersebut mencoba mempengaruhi perilaku orang lain Selain itu berupaya untuk meningkatkan semangat kerja bawahan dengan berbagai bentuk bimbingan, dorongan, dan penghargaan (reward) yang jelas sehingga akan mewujudkan kualitas kerja yang baik.

PD. BPR Bank Daerah Lamongan memiliki budaya kerja yang disebut dengan PT. PRODIC, yang merupakan tuntunan perilaku insan Bank Daerah, yang terdiri dari 6 (enam) Nilai Budaya Kerja, yaitu Prudential (Kehati-hatian,Taat prosedur dan Taat kode etik), Trust (Integritas, Kompetensi dan Teamwork), Profesional (Handal, Berkontribusi dan Bertanggung jawab), Disiplin (Waktu, Biaya dan Learning), Innovating (Kreaktifitas, Inovasi dan Continous improvement) dan Customer focus (Peduli, Layanan prima dan Memberi solusi).

Dalam melaksanakan suatu pekerjaan perlu adanya motivasi dalam diri karyawan, karena motivasi kerja dapat memberikan energi yang menggerakkan segenap potensi yang ada, menciptakan keinginan yang tinggi yang luhur serta dapat meningkatkan semangat dan kegairahan kerja untuk mencapai tujuan yang ditetapkan seperti ungkapan Mangkunegara dan Prabu (2006) bahwa motivasi adalah kemauan untuk berjuang/berusaha Realita perkembangan saat ini yang penuh tantangan maka motivasi pegawai harus selalu dicharged, agar selalu menumbuhkan keinginan untuk mencapai bahkan melampaui targettarget yang ditetapkan. Motivasi juga merupakan penggerak yang mengarahkan pada tujuan tersebut (Mathis dan Jackson, 2001).

Sejalan dengan hal tersebut PD. BPR Bank Daerah Lamongan berusaha untuk menciptakan kondisi yang terbaik di dalam institusi sebagai tempat kebanggaan untuk berkarya dan berprestasi bagi seluruh pegawai. Gaya kepemimpinan memegang peranan penting pada pengambilan keputusan dalam perencanaan, penggerakkan, pengorganisasian, dan pengawasan pada seluruh tingkatan manajemen PD. BPR Bank Daerah Lamongan. Gaya 
kepemimpinan seseorang harus bisa mengatur bawahan dalam berbagai pola pekerjaan, baik di back office, front office, internal maupun dengan pihak eksternal perusahaan, dengan efektif.

Dipadu dengan budaya kerja yang telah tertanam melalui Prinsip PT. PRODIC, dan motivasi pegawai yang optimal maka produktivitas pegawai dengan sendirinya akan mengarah pada pencapaian target yang ditetapkan.

Dalam pelaksanaan sehari-hari, kadang kala timbul permasalahan yang disebabkan oleh penerapan gaya kepemimpinan yang kurang tepat, turunnya motivasi pegawai, rasa tidak puas, kurang harmonisnya hubungan atasan dan bawahan, timbulnya kecurangan (fraud),dan sebagainya, yang bisa mempengaruhi produktivitas pegawai dalam pencapaian target yang telah ditetapkan.

\section{KAJIAN PUSTAKA \\ Gaya Kepemimpinan}

Gaya kepemimpinan adalah pola tingkah laku yang dirancang sedemikian rupa untuk mempengaruhi bawahannya agar dapat memaksimalkan kinerja yang dimiliki bawahannya sehingga kinerja organisasi dan tujuan organisasi dapat dimaksimalkan.

Seorang pemimpin harus menerapkan gaya kepemimpinan untuk mengelola bawahannya, karena seorang pemimpin akan sangat mempengaruhi keberhasilan organisasi dalam mencapai tujuannya (Waridin dan Bambang Guritno, 2005). Menurut Tjiptono (2006:161) gaya kepemimpinan adalah suatu cara yang digunakan pemimpin dalam berinteraksi dengan bawahannya. Sementara itu, pendapat lain menyebutkan bahwa gaya kepemimpinan adalah pola tingkah laku (kata-kata dan tindakan-tindakan) dari seorang pemimpin yang dirasakan oleh orang lain (Hersey, 2004:29).

Terdapat lima gaya kepemimpinan menurut Siagian (2002), yaitu:

1. Tipe pemimpin yang otokratik Seorang pemimpin yang otokratik ialah seorang pemimpin yang:

$>$ Menganggap organisasi sebagai milik pribadi

$>$ Mengidentikan tujuan pribadi dengan tujuan organisasi

$>$ Menganggap bahwa sebagai alat semata-mata

Tidak mau menerima kritik, saran dan pendapat

$>$ Terlalu tergantung pada kekuasaan formalnya

> Dalam tindaknya penggeraknya sering mempergunakan approach yang mengandung unsur paksaan dan punitif (bersifat menghukum)

2. Tipe pemimpin yang militeristik Perlu diperhatikan terlebih dahulu bahwa yang dimaksud seorang pemimpin tipe militeristik berbeda dengan seorang pemimpin modern. Seorang pemimpin yang bertipe militeristik ialah seorang pemimpin yang memiliki sifat-sifat:

$>$ Dalam menggerakan bawahannya sistem perintah yang sering dipergunakan

$>$ Dalam menggerakan bawahannya senang bergantung pada pangkat dan jabatan

$>$ Senang kepada formalitas yang berlebih-lebihan

$>$ Menuntut disiplin yang tinggi dan kaku dari bawahannya

3. Tipe pemimpin yang paternalistik

$>$ Menganggap bahwa sebagai manusia yang tidak dewasa Bersikap terlalu melindungi 
J Jarang memberikan kesempatan kepada bawahannya untuk mengambil keputusan

$>$ Jarang memberikan kesempatan kepada bawahan untuk mengambil inisiatif

$>$ Jarang memberikan kesempatan kepada bawahan untuk mengembangkan daya kreasi dan fantasi

Sering bersikap mau tahu

4. Tipe pemimpin yang kharismatik

Harus diakui bahwa untuk keadaan tentang seorang pemimpin yang demikian sangat diperlukan, akan tetapi sifatnya yang negatif mengalahkan sifatnya yang positif.

5. Tipe pemimpin yang demokratik

Pengetahuan tentang kepemimpinan telah membuktikan bahwa tipe pemimpin yang demokratis lah yang paling tepat untuk organisasi modern karena:

$>$ Ia senang menerima saran, pendapat dan bahkan kritikan dari bawahan

$>$ Selalu berusaha mengutamakan kerjasama tim dalam usaha mencapai tujuan

> Selalu berusaha menjadikan lebih sukses dari padanya

$>$ Selalu berusaha mengembangkan

kapasitas diri pribadinya sebagai pemimpin

Sedangkan Robinss

(2006) mengidentifikasi

empat jenis gaya kepemimpinan:

1. Gaya kepemimpinan kharismatik

Para pengikut terpacu kemampuan kepemimpinan yang heroik atau yang luar biasa ketika mereka mengamati perilaku-perilaku tertentu pemimpin mereka. Terdapat lima karakteristik pokok pemimpin kharismatik:

a. Visi dan artikulasi. memiliki visi ditujukan dengan sasaran ideal yang berharap masa depan lebih baik dari pada status quo, dan mampu mengklarifikasi pentingnya visi yang dapat dipahami orang lain.

b. Riskio personal. Pemimpin kharismatik bersedia menempuh risikopersonal tinggi, menanggung biaya besar, dan terlibat ke dalam pengorbanan diri untuk meraih visi.

c. Peka terhadap lingkungan. Mereka mampu menilai secara realistiskendala lingkungan dan sumber daya yang dibutuhkan untuk membuat perubahan.

d. Kepekaan terhadap kebutuhan pengikut. Pemimpin kharismatik perseptif (sangat pengertian) terhadap kemampuan orang lain dan responsive terhadap kebutuhan dan perasaan mereka.

e. Perilaku tidak konvensional. Pemimpin kharismatik terlibat dalam perilaku yang dianggap baru dan berlawanan dengan norma.

2. Gaya kepemimpinan transaksional

Pemimpin transaksional merupakan pemimpin yang memandu atau memotivasi para pengikut mereka menuju sasaran yang ditetapkan dengan memperjelas persyaratan peran dan tugas. Gaya kepemimpinan transaksional lebih berfokus pada hubungan pemimpin-bawahan tanpa adanya usaha untuk menciptakan perubahan bagi bawahannya. Terdapat empat karakteristik pemimpin transaksional:

a. Imbalan kontingen: kontrak pertukaran imbalan atas upaya yang dilakukan, menjanjikan imbalan atas kinerja baik, mengakui pencapaian.

b. Manajemen berdasar pengecualian (aktif): melihat dean mencari penyimpangan 
dari aturan dan standar, menempuh tindakan perbaikan.

c. Manajemen berdasar pengecualian (pasif): mengintervensi hanya jika standar tidak dipenuhi.

d. Laissez-Faire: melepas tanggung jawab, menghindari pembuatan keputusan.

3. Gaya kepemimpinan transformasional

Pemimpin transformasional mencurahkan perhatian pada halhal dan kebutuhan pengembangan masing-masing

Pemimpin pengikut. mengubah kesadaran para pengikut akan persoalan-persoalan dengan membantu mereka memandang masalah lama dengan cara-cara baru, dan mereka mampu menggairahkan, membangkitkan, dan mengilhami para pengikut untuk mengeluarkan upaya ekstra demi mencapai sasaran kelompok. Ada empat karakteristik pemimpin transformasional:

a. Kharisma: memberikan visi dan rasa atas misi, menanamkan kebanggaan, meraih penghormatan dan kepercayaan.

b. Inspirasi: mengkomunikasikan harapan tinggi, menggunakan symbol untuk memfokuskan pada usaha, menggambarkan maksud penting secara sederhana.

c. Stimulasi mendorong intelektual: dan pemecahan masalah secara hati-hati.

d. Pertimbangan individual: memberikan perhatian pribadi, melayani karyawan secara pribadi, melatih dan menasehati.

4. Gaya kepemimpinan visioner

Kemampuan menciptakan dan mengartikulasikan visi yang realistis, kredibel, dan menarik mengenai masa depan organisasi yang tengah tumbuh dan membaik. Visi ini jika diseleksi dan diimplementasikan secara tepat, mempunyai kekuatan besar yang bisa mengakibatkan terjadinya lompatan awal ke masa depan dengan membangkitkan keterampilan, bakat, dan sumber daya untuk mewujudkannya.

\section{Motivasi Kerja}

Dalam

kehidupan

berorganisasi, pemberian dorongan sebagai bentuk motivasi kerja kepada bawahan penting dilakukan untuk meningkatkan kinerja karyawan. Menurut Malayu (2005: 143), motivasi berasal dari kata latin movere yang berarti dorongan atau pemberian daya penggerak yang menciptakan kegairahan kerja seseorang agar mereka mau bekerja sama, bekerja efektif, dan terintegrasi dengan segala daya upayanya untuk mencapai kepuasan. Motivasi merupakan factor yang kehadirannya dapat menimbulkan kepuasan kerja, dan meningkatkan kinerja karyawan (Umar,1999). Kemudian Siagian (2002) mengatakan bahwa dalam kehidupan berorganisasi, termasuk kehidupan berkarya dalam organisasi, aspek motivasi kerja mutlak mendapat perhatian serius dari para pemimpin yang setiap hari berkontak langsung dengan bawahan di tempat kerja.

Motivasi sendiri adalah reaksi yang timbul dari dalam diri seseorang sebagai dorongan karena adanya rangsangan dari luar yang mempengaruhi untuk memenuhi tujuan tertentu (Suranta,2002).

Berdasarkan pengertian tentang motivasi diatas, disimpulkan bahwa motivasi kerja adalah dorongan atau semangat yang timbul dalam diri seseorang atau karyawan untuk 
melakukan sesuatu atau bekerja, karena adanya rangsangan dari luar baik itu dari atasan serta adanya dasar untuk memenuhi kebutuhan dan rasa puas, serta memenuhi tanggung jawab atas tugas-tugas yang diberikan dan dilakukan dalam organisasi.

Teori-teori Motivasi

\section{Teori Abraham Maslow}

Teori motivasi Abraham maslow (Robins, 2006) mengatakan bahwa di dalam iri semua manusia bersemayam lima jenjang kebutuhan, yaitu sebagai berikut:

1. Fisiologis: antara lain rasa lapar, haus, perlindungan (pakaian dan perumahan), seks, dan kebutuhan jasmani lain.

2. Keamanan: antaranya keselamatan dan perlindungan atas kerugian fisik dan emosional.

3. Sosial: mencakup kasih saying, rasa memiliki, diterima-baik, dan persahabatan.

4. Penghargaan: mencakup faktor penghormatan diri seperti harga diri, otonomi, dan prestasi; serta faktor dari luar misalnya status, pengakuan, dan perhatian.

5. Aktualisasi diri: dorongan untuk menjadi seseorang/sesuatu sesuai ambisinya; yang mencakup pertumbuhan, pencapaian potensi, dan pemenuhan kebutuhan diri.

$>$ Teori David McClelland

Teori McClelland (Robins, 2006) mengatakan 3 poin, yaitu:

1. Kebutuhan akan prestasi: Dorongan untuk mengungguli, berprestasi sehubungan dengan seperangkat standar, bergulat untuk sukses.

2. Kebutuhan akan kekuasaan: kebutuhan untuk membuat orang lain berperilaku dalam suatu cara yang orang-orang itu [tanpa dipaksa] tidak akan berperilaku demikian.
3. Kebutuhan akan afiliasi: hasrat untuk hubungan antar-pribadi yang ramah dan akrab.

\section{METODE PENELITIAN}

Penelitian ini menggunakan metode penelitian kualitatif, dimana metode ini mendeskripsikan secara tepat dan mendalam tentang bagaimana gaya kepemimpinan dan motivasi pegawai di PD. BPR Bank Daerah Lamongan. Fokus penelitian ialah gaya kepemimpinan dan motivasi pegawai di PD. BPR Bank Daerah Lamongan, meliputi : Informan dalam penelitian ini diperoleh dengan kriteria bahwa mereka dapat memberikan informasi yang dibutuhkan dalam penelitian ini, yaitu karyawan PD. BPR Bank Daerah Lamongan berjumlah 84 orang. Didalam rangka pengumpulan data yang diperlukan dalam penelitian ini, maka digunakan teknik dasar sebagai berikut: wawancara, dokumen, dan studi pustaka.

Teknik analisis data dalam penelitian ini menggunakan model analisis interaktif Miles and Huberman (1994), data yang diperoleh di lapangan disajikan dalam bentuk narasi. Hasil pengumpulan data, direduksi, dirangkum sehingga ditemukan tema-tema dan pokok yang dianggap relevan dengan masalah dan tujuan penelitian. Proses selanjutnya verifikasi hal-hal yang sering timbul dan berkaitan dengan masalah yang menjadi fokus penelitian, serta terakhir pengambilan kesimpulan.

\section{HASIL PENELITIAN}

Berikut ini disajikan rangkuman hasil wawancara berdasarkan fokus yang sudah ditanyakan kepada para informan:

1. Gaya kepemimpinan di PD. BPR Bank Daerah Lamongan cenderung ke arah yang partisipatif karena 
mengakomodasi saran, usul dan pendapat dari bawahan dengan menggunakan aturan dan disiplin yang ketat untuk mempengaruhi bawahan, pegawai dituntut untuk melaksanakan ketentuan standard layanan (SOP) untuk frontliner sesuai permintaan atau tuntutan dari manajemen. Pimpinan menerima saran dan usul yang dikemukakan bawahan karena bawahan berada di garis depan (frontliner) dalam menerima komentarkomentar dari nasabah. Menurut para informan, kendalanya masih banyak bank pesaing sehingga harus terus berupaya lagi. Di bidang bisnis, ketika diberikan target mau tidak mau harus berupaya mencapainya walaupun sejauh ini PD. BPR Bank Daerah Lamongan bukan merupakan bank dengan pencapaian laba terbanyak, kendalanya masih banyak bank pesaing yang menonjolkan keunggulannya masing-masing.

2. Motivasi pegawai bekerja di PD. BPR Bank Daerah Lamongan saat ini yaitu ingin mencapai karier yang terbaik, mendapat gaji yang tinggi, fasilitas memadai dan mendapatkan dana pensiun yang memadai. Saat wawancara pegawai mengalami demotivasi dalam pekerjaan. Demotivasi yang dialami pegawai biasanya diakibatkan karena: (1) kejenuhan yang dirasakan selama bekerja, apalagi pegawai yang berada pada posisi / level yang "mentok", (2) menghadapi tekanan pekerjaan karena memenuhi target, (3) perubahan situasi dan kondisi kantor yang tidak terduga, (4) tempat atau posisi yang ditempati sudah terlalu lama sehingga muncul rasa jenuh karena tidak ada variasi dalam bekerja.

\section{PEMBAHASAN}

\section{Gaya Kepemimpinan}

Di PD. BPR Bank Daerah

Lamongan, ditemukan para pegawai yang melaksanakan tugas dan kegiatan kerja diberi petunjuk dari pimpinan sesuai dengan pengaturan personalia di bagian-bagian yang memperhitungkan bobot kerja, target dan tujuan perusahaan. Sudah barang tentu disiplin kerja harus diterapkan dengan sungguh-sungguh dari pimpinan. Kegiatan ini mendorong semangat kerja dari karyawan karena pemimpin juga bersedia menerima masukan dari para karyawan. Pemimpin berkonsultasi dengan pegawai mengenai masalah yang menarik perhatian mereka tentang nasabah dan dimana mereka dapat menyumbangkan sesuatu ide demi memuaskan nasabah. Komunikasi berjalan dengan lancar dari pegawai dengan pimpinan, baik pujian atau kritik bahkan reward and punishment diberlakukan.

$$
\text { Tanggungjawab dalam }
$$

membuat keputusan masih tetap ada pada pemimpin, namun pegawai ikut serta dalam diskusi penetapan saran dan pemecahan masalah. Keikutsertaan pegawai dan pimpinan mendorong komitmen pada keputusan akhir. Locke (1997), mengkategorikan 3 elemen kepemimpinan sebagai proses membujuk (inducing) orang-orang lain untuk mengambil langkah menuju suatu sasaran bersama, yaitu: (1) kepemimpinan merupakan suatu konsep relasi, (2) kepemimpinan merupakan suatu proses, (3) kepemimpinan harus membujuk orangorang lain untuk mengambil tindakan.

Sejauh ini setiap pegawai melaksanakan pekerjaannya semaksimal mungkin sesuai tuntutan manajemen tanpa ada tawar menawar terutama menyangkut standard layanan 
khusus frontliner demi kemajuan PD. BPR Bank Daerah Lamongan. Di bidang layanan, pegawai Bank Daerah Lamongan sudah berusaha semaksimal mungkin, didukung oleh role play dan penguasaan standard layanan. Hal ini dirasakan oleh pegawai sebagai suatu tekanan dalam pekerjaan bahkan dianggap terlalu ketat, tegas dan disiplin.

Seperti diketahui PD. BPR Bank Daerah Lamongan memiliki budaya kerja yang disebut dengan PT. PRODIC, yang merupakan tuntunan perilaku insan Bank Daerah Lamongan, yang terdiri dari 6 (enam) Nilai Budaya Kerja, yaitu yaitu Prudential (Kehatihatian,Taat prosedur dan Taat kode etik), Trust (Integritas, Kompetensi dan Teamwork), Profesional (Handal, Berkontribusi dan Bertanggung jawab), Disiplin (Waktu, Biaya dan Learning), Innovating (Kreaktifitas, Inovasi dan Continous improvement) dan Customer focus (Peduli, Layanan prima dan Memberi solusi).

Menurut Wahjosumidjo (1992)

kepemimpinan diperlukan dalam semua organisasi untuk mempengaruhi individu atau kelompok sehingga melakukan kegiatan atau pekerjaan dengan penuh tanggungjawab. Keberhasilan dan kegagalan suatu organisasi tergantung pada pemimpinnya.

Teladan pimpinan sangat diperlukan untuk menegakkan disiplin. Peraturan-peraturan yang dikeluarkan dalam rangka penegakan disiplin akan lebih efektif jika pimpinan memberikan contoh yang baik dalam menerapkan peraturan itu. Misalnya, untuk menegakkan disiplin agar pegawai datang tepat waktu, maka hendaknya pimpinan datang tepat waktu. Pemimpin juga harus bersikap bersahabat dalam kepemimpinannya, agar supaya peraturan-paraturan yang ditetapkan tidak kaku.

\section{Motivasi Kerja Pegawai}

Hasil penelitian yang ditemukan pada PD. BPR Bank Daerah Lamongan, motivasi kerja pegawai berbeda-beda., ada yang bekerja demi mendapatkan uang untuk memenuhi kebutuhan hidup, ada juga yang bekerja untuk status sosial karena kebutuhan hidup sudah berkecukupan dan ada yang bekerja karena bangga menjadi pegawai dan ingin mencapai ke tingkat yang lebih tinggi. Motivasi mereka berbeda-beda pula, yang bekerja keras untuk mendapatkan gaji dan insentif, maupun bekerja keras untuk mendapatkan posisi tertentu dalam jabatannya.

Ada pegawai yang termotivasi karena status sosial, menginginkan pengakuan sebuah prestasi. Ada pegawai yang lebih mementingkan kepuasan pada saat mencapai target (bisnis dan layanan) yang jika tercapai akan mendapatkan pengakuan atas prestasi jika dibandingkan imbalan atas kinerja tersebut. Didalam hal ini bukan berarti tidak mengharapkan imbalan, tetapi menyukai tantangan. Intinya yang mempengaruhi motivasi seseorang bekerja ialah tujuan bekerja masing-masing individu.

PD. BPR Bank Daerah Lamongan memberikan motivasi kepada pegawai berupa upah/gaji yang diberikan setiap bulannya, jaminan dalam pekerjaan (asuransi kesehatan), status sosial sebagai karyawan BUMD, penghargaan terhadap prestasi yang berupa insentif dan promosi jabatan, jasa produksi (jasprod) dan lainnya. Ada pegawai yang menyatakan bahwa motivasinya bekerja di PD. BPR Bank Daerah Lamongan saat ini yaitu ingin mencapai karier yang terbaik, mendapat gaji yang tinggi, fasilitas 
memadai dan mendapatkan dana pensiun yang memadai.

Motivasi pegawai PD. BPR

Bank Daerah Lamongan secara keseluruhan baik, apalagi bagi pegawai-pegawai yang berusia muda memiliki semangat tinggi untuk berkarier di PD. BPR Bank Daerah Lamongan. Sedangkan untuk pegawai senior yang kariernya/posisinya sudah mentok (tidak lagi memiliki kesempatan untuk promosi) memiliki motivasi kerja yang biasa-biasa saja (rendah). Bagi pegawai yang akan memasuki masa pensiun, merasa tenang, aman dan tidak bingung lagi, sehingga kalaupun diberi promosi dengan tantangan yang lebih luas lagi mereka tidak begitu respek bahkan kadang menolaknya.

Menurut teori Dua Faktor (Two Factors) dari Frederick Herzberg, yang menyatakan bahwa pekerja dalam melaksanakan pekerjaannya dipengaruhi oleh dua faktor utama yaitu: Pertama, faktor-faktor pemeliharaan (Maintenance Factors) yang berhubungan dengan hakikat pekerja yang ingin memperoleh ketentraman badaniah. seperti gaji, kepastian pekerjaan dan supervisi yang baik. Kedua, faktor-faktor motivasi (Motivation Factors) yang menyangkut kebutuhan psikologis yang berhubungan dengan penghargaan terhadap pribadi yang secara langsung seperti ruangan yang nyaman, penempatan kerja yang sesuai dan lainnya.

Keberhasilan manajemen untuk meningkatkan produktivitas kerja pegawai di PD. BPR Bank Daerah Lamongan juga sangat ditentukan oleh motivasi kerja pegawai secara keseluruhan. Karena, kepemimpinan dan disiplin kerja berkaitan erat dengan motivasi kerja pegawai.

\section{KESIMPULAN DAN SARAN Kesimpulan}

Berdasarkan hasil penelitian dan pembahasan yang telah dikemukakan, maka dapat disimpulkan sebagai berikut:

1. Kepemimpinan yang diterapkan di PD. BPR Bank Daerah Lamongan menekankan pada gaya partisipatif. Pemimpin dan anggota saling berkonsultasi dalam mengambil keputusan terkait dengan keadaan nasabah

2. Motivasi kerja pegawai berbedabeda sesuai dengan tingkat senioritasnya. Pegawai yang masih yunior dimotivasi oleh insentif, bonus,promosi jabatan dan karier sebagai eksistensi harga diri dalam status sosial di masyarakat. Pegawai yang senior dimotivasi oleh jaminan hari tua berupa dana pensiun.

\section{Saran}

Berdasarkan kesimpulan yang sudah dikemukakan maka saran yang bisa disampaikan yakni sebagai berikut:

1. Di dalam meningkatkan kinerja bank yang sesuai dengan tujuan, visi dan misi Bank Daerah Lamongan maka gaya kepemimpinan yang partisipatif hendaklah dipertahankan bahkan disesuaikan dengan mendengarkan apa yang diinginkan nasabah sebagai customer.

2. Pimpinan memperhatikan pegawai yang mengalami demotivasi yang disebabkan karena terlalu jenuh dengan situasi dan kondisi tempat kerja dengan memberikan variasi tugas, dan menciptakan suasana yang kondusif di tempat kerja. 


\section{DAFTAR PUSTAKA}

Fandy Tjiptono, 2006, Manajemen Pelayanan Jasa, Penerbit Andi, Yogyakarta. Guritno,Bambang dan Waridin. (2005). Pengaruh Persepsi Karyawan Mengenai Perilaku Kepemimpinan, Kepuasan Kerja dan Motivasi Terhadap Kinerja. Jurnal Riset Bisnis Indonesia Vol.1 No.1, p. 63-74.

Guritno,Bambang dan Waridin. (2005). Pengaruh Persepsi Karyawan Mengenai Perilaku Kepemimpinan, Kepuasan Kerja dan Motivasi Terhadap Kinerja. Jurnal Riset Bisnis Indonesia Vol.1 No.1, p. 63-74.

Hersey, 2004. Kunci Sukses Pemimpin Situasional. Jakarta Delaprasata.

Hasibuan, Malayu. 2004. Manajemen Sumber Daya Manusia. Bumi Aksara, Jakarta.

Husein Umar, Riset SDM dalam Organisasi, (Yogyakarta : PT. Gramedia pustaka utama, 1999),p, 16

Locke, E A . 1997. Esensi Kepemimpinan. Empat Kunci Untuk Memimpin Dengan Penuh Keberhasilan. Spektrum Utama Pegawai Prentince-Hall.

Mangkunegara, A.A Anwar Prabu. 2006, Manajemen Sumber Daya Manusia Perusahaan. Rosdakarya. Bandung

Mathis, R.L. dan J. H. Jackson. 2001. Manajemen Sumberdaya Manusia. Edisi Pertama. Salemba Empat

Miles, M. B. \& Huberman N. 1994. Analisis Data Kualitatif.PT. Gramedia Pustaka Utama, Jakarta.

Robbins, Stephen. P. 2006. Perilaku organisasi. Edisi Bahasa
Indonesia. Indeks Kelompok GRAMEDIA. Jakarta.

Siagian P. Sondang. 2002. Kiat Meningkatkan Produktivitas Kerja. Jakarta : Rineka

Cipta.

Suranta, Sri. 2002. Dampak Motivasi Karyawan Pada Hubungan Antara Gaya Kepemimpinan Dengan Kinerja Karyawan Perusahaan Bisnis. Empirika.

Susanto, A. B (1997).Budaya Perusahaan, Seri Manajemen dan Persaingan Bisnis.Cetakan Pertama. Elex Media Komputindo. Jakarta

Thoha, M. 2004, Dimensi-dimensi Prima Ilmu Administrasi Negara. Raja Grafindo Persada. Jakarta

Wahjosumidjo. 1992. Kepemimpinan Motivasi. Ghalia Indonesia. Jakarta. 